\title{
Free radical scavenging and a-glucosidase inhibitory activities of the extracts of Dystaenia takesimana from Ulleung Island
}

\author{
Jeong Hun Kim, Gyeong Han Jeong, Yong-Ha Jeong, Tae Hoon Kim* \\ Department of Food Science and Biotechnology, Daegu University, Gyeongsan 38453, Korea
}

\section{울릉 섬바디 추출물의 라디칼 소거 및 $\mathrm{a}$-glucosidase 저해 활성}

\author{
김정훈 · 정경한 · 정용하·김태훈* \\ 대구대학교 식품공학과
}

\begin{abstract}
In this study, we investigated the free radical scavenging and a-glucosidase inhibitory activities of an aqueous methanolic extract from Dystaenia takesimana sourced from Ulleungdo. Seventy percent of the methanolic extract from $D$. takesimana was further divided into $n$-hexane, EtOAc and $n$-BuOH fractions, which yielded four solvent-soluble portions, namely $n$-hexane-soluble, EtOAc-soluble, $n$-BuOH-soluble, and $\mathrm{H}_{2} \mathrm{O}$ residues. Antioxidant properties were evaluated using the common 1,1-diphenyl-2-picrylhydrazyl (DPPH) and 2,2'-azino-bis (3-ethylbenzothiazoline-6-sulfonic acid) $\left(\right.$ ABTS $^{+}$) radicals scavenging assays, while the anti-diabetic efficacy of the $D$. takesimana extract and the solvent-soluble portions were tested using an a-glucosidase assay. All samples exhibited dose-dependent radical scavenging and a-glucosidase inhibitory activities. Among the tested extracts and solvent-soluble fractions, the EtOAc-soluble portion exhibited a much higher radical scavenging activity compared to the other solvent-soluble portions. a-Glucosidase inhibitory $\mathrm{IC}_{50}$ values of $55.5 \pm 0.4$ and $229.3 \pm 2.3 \mathrm{\mu g} / \mathrm{mL}$ were determined for the $n$-hexane-soluble and EtOAc-soluble portions, respectively. These results suggest that the $D$. takesimana extract is a potential new source of natural antioxidants and anti-diabetic agents.
\end{abstract}

Key words : Dystaenia takesimana, total phenolics content, DPPH, $\mathrm{ABTS}^{+}$, a-glucosidase

\section{서 론}

현대인들은 자외선, 흡연, 매연, 약물 및 방사선 등의 다 양한 요인과 산화 촉진물질로 인하여 인체의 항산화 방어체 계의 균형이 깨어진다. 이로 인해 생성된 superoxide $\left(\mathrm{O}^{2-}\right)$, nitric oxide(NO), nitrogen dioxide $\left(\mathrm{NO}_{2}\right)$, hydroxyl $(\mathrm{OH})$, peroxynitrite(ONOO) 등과 같은 활성 산소 종(reactive oxygen species, ROS)은 인체 내에서 산화를 유발하여 산화 적 스트레스를 촉진한다 $(1,2)$. 인체의 과도한 산화적 스트 레스는 세포의 구성성분인 지질, 단백질, 당 및 DNA 등의

*Corresponding author. E-mail : skyey7@daegu.ac.kr Phone : 82-53-850-6533, Fax : 82-53-850-6539

Received 02 January 2019: Revised 18 February 2019; Accepted 20 February 2019.

Copyright (c) The Korean Society of Food Preservation. All rights reserved.
비선택적, 비가역적 파괴를 촉진하여 노화 촉진 및 각종 질병을 유발하는데 특히 암, 뇌질환, 실혈관계질환 및 피부 질환 등과 밀접한 관계가 있다(3-5). 체내의 ROS 또는 자유 라디칼을 중화시켜 노화방지 및 성인병 예방 등의 기능을 하는 성분을 항산화 물질이라고 하며, 대표적인 항산화제 로서 butylated hydroxy anisol(BHA), butylated hydroxy toluene(BHT) 등의 합성 항산화제가 사용되었으나 $(6,7)$ 암, 지질대사 불균형 등의 부작용이 발견되어 사용을 제한하고 있다(8). 따라서 보다 안전하고 부작용이 적은 천연물 유래 의 천연 항산화제의 관심 증가와 개발이 지속적으로 이루어 지고 있다(9).

최근 급격한 경제성장 및 생활수준의 향상으로 인해 서 구화된 식습관으로의 변화가 가속화됨에 따라 만성 대사성 질환 중 하나인 당뇨병의 발병률이 증가하고 있다(10). 당뇨 병은 제 1 형 및 제 2 형 당뇨병으로 구분되며, 제 1 형 당뇨병 은 췌장 베타세포의 병변에 따른 인슐린 결핍으로 인한 
인슐린 의존성이고, 제2형 당뇨병은 인슐린 저항성으로 인 한 인슐린 비의존성 당뇨병으로 정의된다(11). 최근의 보고 에 따르면 췌장 베타세포의 손상이 산화적 스트레스에 의해 발생되고 이것이 곧 인슐린 분비감소로 이어져 항산화 물질 이 당뇨병 개선과 밀접한 연관성이 보고되어 져있다(12). 한편 a-glucosidase는 소장점막에 존재하는 당분해효소로 서 이를 저해하면 탄수화물의 소화 및 흡수를 방해하여 식후 급격한 혈당상승을 억제하여 고혈당을 예방하는 작용 을 한다(13). 대표적인 a-glucosidase 저해제로는 acarbose 및 voglibose가 알려져 있으나, 이들의 장기 복용 시 각종 부작용을 유발하는 것이 알려져있다(14). 따라서 천연물 유래의 보다 안전하고 우수한 효능을 가진 a-glucosidase 저해제의 탐색이 필요한 실정이다. 현재까지 천연물로부터 a-glucosidase 저해제의 분리 및 동정에 관한 다양한 연구가 보고되어져 있으며(15), 최근에는 a-glucosidase 저해활성 이 우수한 신규의 prenylflavonoid, gallotannin, butyrolactone glucoside 및 chalcone 등의 화합물이 동정 되었다(16-20).

섬바디(Dystaenia takeshimana)는 산형과에 속하는 다년 생 초본식물로 울릉도 전 지역에서 자생하며, 전통의학에 서 과실 또는 뿌리를 약용으로 사용하였다(21). 최근 연구에 서 섬바디의 뿌리 추출물로부터 coumarin, flavonoid 및 terpenoid류의 화합물이 동정 되었으며, 이들 화합물의 항염 증 활성이 보고되어졌다(22), 또한 전북 고창 지역에서 재배 된 섬바디 $\mathrm{EtOH}$ 추출물로부터 항균 활성이 우수한 polyacetylene류의 화합물의 존재가 보고되어졌다(23). 그 러나 울릉도 자생 섬바디에 대한 생리활성 또는 성분에 대한 연구는 전무한 실정이다. 따라서 본 연구에서는 울릉 도 자생 섬바디 전초 추출물 및 극성별 유기용매를 활용한 각 분획물에 대하여 항산화 활성과 관련된 DPPH 및 $\mathrm{ABTS}^{+}$ 라디칼 소거능, 항 당뇨 활성과 관련된 a-glucosidase 저해활
성 평가에서 우수한 활성을 확인하였기에 그 결과를 보고하 고자 한다.

\section{재료 및 방법}

\section{재 료}

본 실험에 시료는 경상북도 울릉군에서 2009년 5월에 채취한 건조된 섬바디(Dystaenia takeshimana) 전초를 사용 하였다. 표본시료는 대구대학교의 식품공학과 천연물 화학 실험실에 보관하고 있으며, 기능성 평가에 사용된 시약은 gallic acid, 1,1-diphenyl-2-picrylhydrazyl(DPPH), 2,2'-azinobis3-ethylbenzothiazoline-6-sulfonic acid(ABTS $\left.{ }^{+}\right)$, Saccharomyces cerevisiae 유래의 a-glucosidase, (+)-catechin 및 acarbose은 Sigma-Aldrich Chemical Co.(St. Louis, MO, USA)에서 구입 하여 사용하였고, 그 외에 사용된 용매 및 시약은 모두 일급 이상의 등급을 사용하였다.

\section{추출물의 제조 및 분획}

건조된 울릉 섬바디 전초 $2.0 \mathrm{~kg}$ 을 분쇄기로 잘게 마쇄한 후, $70 \%$ methyl alcohol(MeOH) $10.0 \mathrm{~L}$ 로 상온에서 침지추출 을 3일간 3회 반복하여 여과 한 후 농축하였다. 얻어진 울릉 섬바디 $70 \% \mathrm{MeOH}$ 추출물 $(120.4 \mathrm{~g})$ 을 물에 현탁하여 저극 성 용매인 $n$-hexane으로 먼저 분획한 후 수층을 다시 ethyl acetate $(\mathrm{EtOAc})$ 와 $n$-butyl alcohol $(n-\mathrm{BuOH})$ 을 이용하여 각 각 순차적으로 3 회 분획하였다. 각 용매추출 분획을 저온 감압 농축한 뒤 건조하여 $n$-hexane 분획물 $(12.1 \mathrm{~g}), \mathrm{EtOAc}$ 분획물 $(8.4 \mathrm{~g}), n-\mathrm{BuOH}$ 분획물(13.9 g), $\mathrm{H}_{2} \mathrm{O}$ 분획물(79.3 $\mathrm{g}$ )을 각각 수득하였다(Fig. 1). 농축된 섬바디 $70 \% \mathrm{MeOH}$ 추출물과 유기용매를 이용한 각 분획물을 대상으로 총 페놀

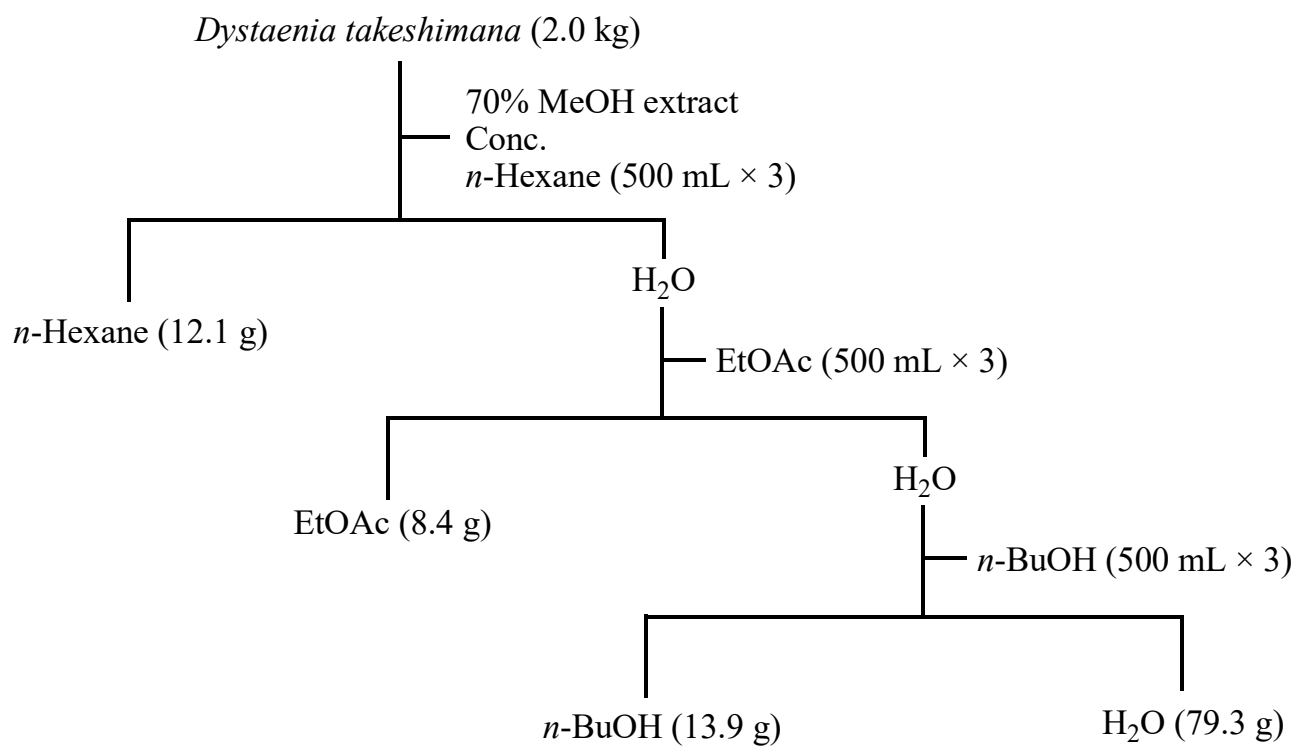

Fig. 1. Liquid-liquid partition of Dystaenia takeshimana from Ulleung Island origin. 
함량 측정, $\mathrm{DPPH}$ 및 $\mathrm{ABTS}^{+}$라디칼 소거활성 및 $\mathrm{a}$ -glucosidase 저해활성 평가를 수행하였다.

\section{총 페놀성 화합물 함량 측정}

울릉 섬바디 $70 \% \mathrm{MeOH}$ 추출물 및 유기용매 분획물의 총 페놀성 화합물의 함량은 Folin-Denis 방법(24)에 따라 측정하였으며, 추출물 혹은 분획물을 $1.0 \mathrm{mg} / \mathrm{mL}$ 농도로 조제한 후, 시료 $50 \mu \mathrm{L}$ 와 Folin-Denis 시액 $50 \mu \mathrm{L}, 0.7 \mathrm{M}$ 탄산나트륨 포화용액 $50 \mu \mathrm{L}$ 를 차례로 넣은 다음 이것을 잘 혼합하여 실온에서 60 분 방치한 후 UV/VIS 분광광도계 로 $750 \mathrm{~nm}$ 에서 흡광도를 측정하였으며, 표준물질은 gallic $\mathrm{acid}$ 를 이용하여 표준곡선을 작성하여 양을 환산하였다.

\section{$\mathrm{DPPH}$ 라디칼 소거능 측정}

울릉도에 자생하는 섬바디 $70 \% \mathrm{MeOH}$ 추출물 및 분획물 의 전자공여능은 Blois 방법(25)에 따라 측정하였다. 각 시 료용액 $120 \mu \mathrm{L}$ 에 $0.45 \mathrm{mM}$ 의 DPPH 용액 $60 \mu \mathrm{L}$ 을 넣고 교반한 후 15 분간 방치한 다음 $517 \mathrm{~nm}$ 에서 흡광도를 측정 하였다. 이 때 양성 대조군은 천연 항산화제인 (+)-catechin 을 사용하였다.

$$
\text { DPPH radical scavenging activity }(\%)=\left(1-\frac{\mathrm{A}_{\text {sample }}-\mathrm{A}_{\text {blank }}}{\mathrm{A}_{\text {conrol }}}\right) \times 100
$$

결과는 첨가군 $\left(\mathrm{A}_{\text {sample }}\right)$ 과 무첨가군 $\left(\mathrm{A}_{\text {blank }}\right)$ 의 흡광도 감소 율 차이를 백분율로 환산하여 나타내었다.

\section{$\mathrm{ABTS}^{+}$라디칼 소거능 측정}

울릉 섬바디의 $70 \% \mathrm{MeOH}$ 추출물 및 분획물에 대하여 $\mathrm{ABTS}^{+}$radical 소거능을 $\mathrm{Re}(26)$ 의 방법을 변형하여 다음과 같이 측정하였다. $7 \mathrm{mM} \mathrm{ABTS}{ }^{+}$와 $2.4 \mathrm{mM} \mathrm{K}_{2} \mathrm{O}_{8} \mathrm{~S}_{2}$ 동량을 혼합 후 실온, 암실에서 12 시간 방치하여 라디칼의 생성을 유도한 후 $\mathrm{ABTS}^{+}$라디칼 용액을 희석하여 $734 \mathrm{~nm}$ 에서 흡광도 값이 0.7-0.8 정도가 되도록 희석한 후 사용하였다. 희석한 $\mathrm{ABTS}^{+}$라디칼 용액 $100 \mu \mathrm{L}$ 와 섬바디 추출물 및 분획물 $100 \mu \mathrm{L}$ 를 혼합하여 실온에서 7 분간 반응시킨 후 $734 \mathrm{~nm}$ 에서 흡광도를 측정하였다. 이 때 양성대조군은 천 연 항산화제인 (+)-catechin을 사용하였다.

$$
\mathrm{ABTS}^{+} \text {radical scavenging activity }(\%)=\left(1-\frac{\mathrm{A}_{\text {sample }}-\mathrm{A}_{\text {blank }}}{\mathrm{A}_{\text {conrol }}}\right) \times 100
$$

결과는 첨가군 $\left(\mathrm{A}_{\text {sample }}\right)$ 과 무첨가군 $\left(\mathrm{A}_{\text {blank }}\right)$ 의 흡광도 감소 율 차이를 백분율로 환산하여 나타내었다.

\section{a-Glucosidase 저해활성 측정}

a-Glucosidase 저해능은 $\operatorname{Kim}(27)$ 이 행한 방법을 변형하
여 효소-기질반응을 이용한 분광학적 방법으로 측정하였 다. 즉, $1 \mathrm{U} / \mathrm{mL}$ a-glucosidase $90 \mu \mathrm{L}$ 에 시료 혹은 $0.1 \mathrm{M}$ sodium phosphate buffer(pH 6.8) $10 \mu \mathrm{L}$ 를 첨가하여 혼합한 후 $37^{\circ} \mathrm{C}$ 에서 15 분 동안 incubation 시켰다. 반응 후 기질인 $1 \mathrm{mM} p$-NPG $100 \mu \mathrm{L}$ 를 첨가한 후 5분간 반응시키고 405 $\mathrm{nm}$ 에서 ELISA reader를 이용하여 흡광도를 측정함으로써 기질로부터 유리되어 나오는 p-nitrophenol을 측정하였다. 양성 대조군으로 대표적인 a-glucosidase 저해제로 잘 알려 진 acarbose를 사용하였다.

$$
\text { a-Glucosidase inhibitory effect }(\%)=\left(1-\frac{A_{\text {sample }}-A_{\text {blank }}}{A_{\text {conrol }}}\right) \times 100
$$

a-Glucosidase 저해활성의 결과는 첨가군 $\left(\mathrm{A}_{\text {sample }}\right)$ 과 무첨 가군 $\left(\mathrm{A}_{\mathrm{blank}}\right)$ 의 흡광도 감소율 차이를 백분율로 환산하여 나타내었다.

\section{통계처리}

실험결과는 SPSS package program(version 20.0, SPSS Inc., Chicago, IL, USA)을 이용하여 각 실험군 간의 유의성 을 검증한 후 Duncan's multiple range test에 의해 실험군 간의 차이를 $\mathrm{p}<0.05$ 유의수준에서 검증하였다.

\section{결과 및 고찰}

\section{총 페놀성 화합물 함량}

울릉도 전역에 자생하는 섬바디 $70 \% \mathrm{MeOH}$ 추출물 및 각 유기용매 분획물에 함유하고 있는 총 페놀성 함량은 Table 1에 나타내었다. 그중 섬바디 $70 \% \mathrm{MeOH}$ 추출물은 $1 \mathrm{~g}$ 당 $46.6 \pm 1.1 \mathrm{mg} \mathrm{GAE} / \mathrm{g}$ 을 함유하고 있었으며, EtOAc 분획물은 $98.1 \pm 2.3 \mathrm{mg} \mathrm{GAE} / \mathrm{g}$ 으로 가장 많은 페놀성 화합물 을 함유하고 있었다. 그 외 $n-\mathrm{BuOH}$ 및 $\mathrm{H}_{2} \mathrm{O}$ 분획물은 각 $66.6 \pm 1.8,39.4 \pm 0.9 \mathrm{mg} \mathrm{GAE} / \mathrm{g}$ 의 순으로 페놀성 화합물의 함량이 확인되었으며, $n$-hexane 분획물은 $21.0 \pm 0.5 \mathrm{mg}$

Table 1. Total phenolics contents of $70 \%$ methanolic extract and organic solvent fractions of $D$. takeshimana from Ulleung island

\begin{tabular}{cc}
\hline Samples & Total phenolics contents $(\mathrm{mg} \mathrm{GAE} / \mathrm{g})^{1)}$ \\
\hline $70 \% \mathrm{MeOH}$ ext. & $46.6 \pm 1.1^{2)(3)}$ \\
$n$-Hexane layer & $21.0 \pm 0.5^{\mathrm{e}}$ \\
EtOAc layer & $98.1 \pm 2.3^{\mathrm{a}}$ \\
$n$-BuOH layer & $66.6 \pm 1.8^{\mathrm{b}}$ \\
$\mathrm{H}_{2} \mathrm{O}$ layer & $39.4 \pm 0.9^{\mathrm{d}}$ \\
\hline
\end{tabular}

${ }^{1)} \mathrm{GAE}$, gallic acid equivalents.

${ }^{2)}$ Data represent the mean \pm SD three replications.

${ }^{3}$ Different letters (a-e) within the same column indicate significant differences $(\mathrm{p}<0.05)$. 
$\mathrm{GAE} / \mathrm{g}$ 으로 상대적으로 낮은 페놀성 화합물을 함유하고 있는 것으로 확인되었다.

\section{$\mathrm{DPPH}$ 라디칼 소거능 측정}

보라색을 띄는 DPPH 라디칼은 $517 \mathrm{~nm}$ 부근에서 최대 흡광도를 가지며, 항산화 활성이 우수한 물질과 반응하면 노란색으로 탈색되며 흡광도 값이 감소하게 되는 원리를 활용하여 천연소재의 항산화제 연구 개발에 많이 이용되고 있다(24). Table 2에 나타낸 것처럼 울릉 섬바디 $70 \% \mathrm{MeOH}$ 추출물 및 각 유기용매 분획물에 대해서 $\mathrm{DPPH}$ 라디칼 소거 활성을 평가한 결과, $70 \% \mathrm{MeOH}$ 추출물의 $\mathrm{IC}_{50}$ 값이 $213.9 \pm 3.4 \mu \mathrm{g} / \mathrm{mL}$ 의 활성을 나타났다. $\mathrm{H}_{2} \mathrm{O}$ 및 $n$-hexane 분획 물의 경우 각 $492.2 \pm 4.6,>500 \mu \mathrm{g} / \mathrm{mL}$ 으로 상대적으로 낮은 $\mathrm{IC}_{50}$ 값을 나타냈으며, $n-\mathrm{BuOH}$ 분획물의 경우 $\mathrm{IC}_{50}$ 값은 $247.3 \pm 3.5 \mu \mathrm{g} / \mathrm{mL}$ 로 우수한 $\mathrm{DPPH}$ 라디칼 소거활성을 나타 내었다. 또한 $\mathrm{EtOAc}$ 분획물에 $\mathrm{DPPH}$ 라디칼 소거활성의 $\mathrm{IC}_{50}$ 값이 $127.3 \pm 2.1 \mathrm{\mu g} / \mathrm{mL}$ 로 가장 우수한 활성을 나타냈으 며, 이 결과는 페놀성 화합물의 함량과 $\mathrm{DPPH}$ 라디칼 소거 활성 사이에 밀접한 상관 관계가 있다는 보고와도 일치하는
결과이다(28). 최근 연구에서 울릉도 약용식물인 섬기린초 (Sedum takesimense)의 전초 추출물에서 우수한 DPPH 라디 칼 소거활성이 보고 되었으며, 활성을 나타내는 새로운 페 놀 화합물인 2,6-di- $O$-galloylarbutin 및 gossypetin-8-O $\beta$ -D-xyloside가 구조 동정되었다(29).

\section{$\mathrm{ABTS}^{+}$라디칼 소거능 측정}

울릉 섬바디 $70 \% \mathrm{MeOH}$ 추출물 및 유기용매 분획물을 대상으로 $\mathrm{ABTS}^{+}$라디칼 소거활성 평가를 수행하였다. 그 결과(Table 3), $70 \% \mathrm{MeOH}$ 추출물의 경우 $\mathrm{IC}_{50}$ 값이 $200.3 \pm 2.7 \mu \mathrm{g} / \mathrm{mL}$ 로 우수한 $\mathrm{ABTS}^{+}$라디칼 소거활성이 나타 났으며, $n-\mathrm{BuOH}$ 분획물 및 $\mathrm{H}_{2} \mathrm{O}$ 분획물에서 $\mathrm{IC}_{50}$ 값이 $165.2 \pm 2.5,365.9 \pm 3.8 \mu \mathrm{g} / \mathrm{mL}$ 로 준수한 라디칼 소거활성을 확인되었다. DPPH 라디칼 소거능에서 가장 우수한 활성을 나타낸 $\mathrm{EtOAc}$ 분획물에서 $\mathrm{IC}_{50}$ 값이 $72.7 \pm 1.2 \mu \mathrm{g} / \mathrm{mL}$ 로 가장 우수한 $\mathrm{ABTS}^{+}$라디칼 소거 활성을 나타났으며, $n$-hexane 분획물의 경우 $\mathrm{IC}_{50}$ 값이 $>500 \mu \mathrm{g} / \mathrm{mL}$ 이상으로 상대적으로 낮은 소거활성이 확인되었다. Table 1 및 2에 나타낸 바와 같이 EtOAc 분획물에서 가장 우수한 $\mathrm{DPPH}$ 라디칼 소거활

Table 2. DPPH radical scavenging activity of $70 \%$ methanolic extract of $D$. takeshimana from Ulleung Island and its organic solvent-soluble portions

\begin{tabular}{|c|c|c|c|c|c|c|}
\hline \multirow{2}{*}{ Samples } & \multicolumn{5}{|c|}{ Scavenging activity (\%) } & \multirow{2}{*}{$\begin{array}{c}\mathrm{IC}_{50} \\
(\mu \mathrm{g} / \mathrm{mL})\end{array}$} \\
\hline & $500 \mu \mathrm{g} / \mathrm{mL}$ & $250 \mu \mathrm{g} / \mathrm{mL}$ & $125 \mu \mathrm{g} / \mathrm{mL}$ & $62.5 \mu \mathrm{g} / \mathrm{mL}$ & $31.3 \mu \mathrm{g} / \mathrm{mL}$ & \\
\hline $70 \% \mathrm{MeOH}$ ext. & $77.3 \pm 1.3^{1)(2)}$ & $55.9 \pm 0.8^{c}$ & $31.8 \pm 0.5^{c}$ & $14.5 \pm 0.6^{\mathrm{d}}$ & $12.5 \pm 0.3^{\mathrm{c}}$ & $213.9 \pm 3.4^{\mathrm{d}}$ \\
\hline$n$-Hexane layer & $33.8 \pm 0.9^{\mathrm{f}}$ & $20.7 \pm 0.2^{\mathrm{f}}$ & $14.9 \pm 0.4^{\mathrm{f}}$ & $7.2 \pm 0.3^{\mathrm{f}}$ & $3.2 \pm 0.3^{\mathrm{f}}$ & $>500^{\mathrm{a}}$ \\
\hline EtOAc layer & $89.5 \pm 1.2^{\mathrm{b}}$ & $66.3 \pm 1.0^{\mathrm{b}}$ & $48.8 \pm 0.6^{b}$ & $28.9 \pm 0.4^{b}$ & $20.5 \pm 0.4^{b}$ & $127.3 \pm 2.1^{\mathrm{e}}$ \\
\hline$n$-BuOH layer & $71.0 \pm 1.0^{d}$ & $50.1 \pm 0.6^{\mathrm{d}}$ & $29.4 \pm 0.5^{\mathrm{d}}$ & $19.4 \pm 0.3^{\mathrm{c}}$ & $12.6 \pm 0.2^{\mathrm{d}}$ & $247.3 \pm 3.5^{\mathrm{c}}$ \\
\hline $\mathrm{H}_{2} \mathrm{O}$ layer & $51.2 \pm 0.8^{\mathrm{e}}$ & $35.0 \pm 0.3^{\mathrm{e}}$ & $23.1 \pm 0.3^{\mathrm{e}}$ & $12.9 \pm 0.2^{\mathrm{e}}$ & $8.7 \pm 0.1^{\mathrm{e}}$ & $492.2 \pm 4.6^{b}$ \\
\hline$(+)-$ Catechin$^{3)}$ & $99.9 \pm 1.8^{\mathrm{a}}$ & $95.6 \pm 1.4^{\mathrm{a}}$ & $88.2 \pm 1.3^{\mathrm{a}}$ & $73.4 \pm 1.3^{\mathrm{a}}$ & $53.5 \pm 1.0^{\mathrm{a}}$ & $22.2 \pm 0.6^{\mathrm{f}}$ \\
\hline
\end{tabular}

${ }^{1)}$ Radical scavenging activities are expressed as the mean \pm SD of triplicate experiments.

${ }^{2)}$ Different letters $(\mathrm{a}-\mathrm{f})$ within the same column indicate significant differences $(\mathrm{p}<0.05)$.

${ }^{3)}(+)$-Catechin was used as a positive control.

Table 3. $\mathrm{ABTS}^{+}$radical scavenging activity of $70 \%$ methanolic extract of $D$. takeshimana from Ulleung Island and its organic solvent-soluble portions

\begin{tabular}{|c|c|c|c|c|c|c|}
\hline \multirow{2}{*}{ Samples } & \multicolumn{5}{|c|}{ Scavenging activity (\%) } & \multirow{2}{*}{$\begin{array}{c}\mathrm{IC}_{50} \\
(\mu \mathrm{g} / \mathrm{mL})\end{array}$} \\
\hline & $500 \mu \mathrm{g} / \mathrm{mL}$ & $250 \mu \mathrm{g} / \mathrm{mL}$ & $125 \mu \mathrm{g} / \mathrm{mL}$ & $62.5 \mu \mathrm{g} / \mathrm{mL}$ & $31.3 \mu \mathrm{g} / \mathrm{mL}$ & \\
\hline $70 \% \mathrm{MeOH}$ ext. & $80.8 \pm 1.3^{1)(2)}$ & $56.0 \pm 1.0^{c}$ & $26.5 \pm 0.8^{c}$ & $14.9 \pm 0.6^{\mathrm{d}}$ & $6.8 \pm 0.2^{\mathrm{d}}$ & $200.3 \pm 2.7^{\mathrm{d}}$ \\
\hline$n$-Hexane layer & $32.0 \pm 0.5^{\mathrm{f}}$ & $12.2 \pm 0.4^{\mathrm{f}}$ & $5.3 \pm 0.4^{\mathrm{f}}$ & $3.1 \pm 0.3^{\mathrm{f}}$ & $0.8 \pm 0.1^{\mathrm{f}}$ & $>500^{\mathrm{a}}$ \\
\hline EtOAc layer & $95.1 \pm 1.2^{\mathrm{b}}$ & $83.3 \pm 1.1^{\mathrm{b}}$ & $74.2 \pm 1.1^{\mathrm{b}}$ & $42.9 \pm 0.8^{\mathrm{b}}$ & $18.5 \pm 0.5^{b}$ & $72.7 \pm 1.2^{\mathrm{e}}$ \\
\hline$n$-BuOH layer & $88.2 \pm 1.0^{\mathrm{d}}$ & $64.2 \pm 0.9^{\mathrm{d}}$ & $36.9 \pm 1.0^{\mathrm{d}}$ & $22.0 \pm 0.8^{\mathrm{c}}$ & $10.7 \pm 0.4^{\mathrm{c}}$ & $165.2 \pm 2.5^{\mathrm{c}}$ \\
\hline $\mathrm{H}_{2} \mathrm{O}$ layer & $64.0 \pm 0.9^{\mathrm{e}}$ & $33.4 \pm 0.7^{\circ}$ & $16.5 \pm 0.6^{\mathrm{e}}$ & $5.6 \pm 0.2^{\mathrm{e}}$ & $3.1 \pm 0.1^{\mathrm{e}}$ & $365.9 \pm 3.8^{b}$ \\
\hline$(+)-C a t e c h i n{ }^{3)}$ & $99.9 \pm 1.8^{\mathrm{a}}$ & $95.8 \pm 1.6^{\mathrm{a}}$ & $88.5 \pm 1.5^{\mathrm{a}}$ & $65.3 \pm 1.0^{\mathrm{a}}$ & $31.9 \pm 0.9^{\mathrm{a}}$ & $18.4 \pm 0.3^{\mathrm{f}}$ \\
\hline
\end{tabular}

\footnotetext{
${ }^{1)}$ Radical scavenging activities are expressed as the mean \pm SD of triplicate experiments.

${ }^{2)}$ Different letters $(a-f)$ within the same column indicate significant differences $(p<0.05)$.

${ }^{3)}(+)$-Catechin was used as a positive control.
} 
Table 4. Inhibitory effects of $70 \%$ methanolic extract of $D$. takeshimana from Ulleung Island and its organic solvent-soluble portions against a-glucosidase

\begin{tabular}{|c|c|c|c|c|c|c|}
\hline \multirow{2}{*}{ Samples } & \multicolumn{5}{|c|}{ Inhibition (\%) } & \multirow{2}{*}{$\begin{array}{c}\mathrm{IC}_{50} \\
(\mu \mathrm{g} / \mathrm{mL})\end{array}$} \\
\hline & $500 \mu \mathrm{g} / \mathrm{mL}$ & $250 \mu \mathrm{g} / \mathrm{mL}$ & $125 \mu \mathrm{g} / \mathrm{mL}$ & $62.5 \mu \mathrm{g} / \mathrm{mL}$ & $31.3 \mu \mathrm{g} / \mathrm{mL}$ & \\
\hline $70 \% \mathrm{MeOH}$ ext. & $47.4 \pm 0.9^{1)(2)}$ & $38.8 \pm 0.9^{\mathrm{d}}$ & $29.3 \pm 0.5^{\mathrm{d}}$ & $19.2 \pm 0.4^{\mathrm{d}}$ & $7.3 \pm 0.4^{\mathrm{d}}$ & $>500^{\mathrm{a}}$ \\
\hline$n$-Hexane layer & $99.9 \pm 1.6^{\mathrm{a}}$ & $90.8 \pm 1.5^{\mathrm{a}}$ & $80.9 \pm 1.3^{\mathrm{a}}$ & $63.8 \pm 1.0^{\mathrm{a}}$ & $47.7 \pm 0.7^{\mathrm{a}}$ & $55.5 \pm 0.4^{\mathrm{d}}$ \\
\hline EtOAc layer & $64.9 \pm 0.9^{c}$ & $53.4 \pm 0.9^{c}$ & $43.4 \pm 0.8^{b}$ & $29.1 \pm 0.7^{b}$ & $12.1 \pm 0.5^{\mathrm{c}}$ & $229.3 \pm 2.3^{\mathrm{b}}$ \\
\hline$n$-BuOH layer & $24.0 \pm 0.6^{\mathrm{e}}$ & $19.0 \pm 0.5^{\mathrm{e}}$ & $11.3 \pm 0.3^{\mathrm{e}}$ & $5.8 \pm 0.2^{\mathrm{e}}$ & $2.7 \pm 0.2^{\mathrm{e}}$ & $>500^{\mathrm{a}}$ \\
\hline $\mathrm{H}_{2} \mathrm{O}$ layer & $5.2 \pm 0.5^{\mathrm{f}}$ & $2.9 \pm 0.3^{\mathrm{f}}$ & $1.5 \pm 0.2^{\mathrm{f}}$ & $0.5 \pm 0.1^{\mathrm{f}}$ & $0.1 \pm 0.03^{\mathrm{f}}$ & $>500^{\mathrm{a}}$ \\
\hline Acarbose $^{3)}$ & $69.1 \pm 1.1^{\mathrm{b}}$ & $56.7 \pm 1.1^{\mathrm{b}}$ & $41.2 \pm 0.8^{c}$ & $29.3 \pm 0.7^{\mathrm{c}}$ & $15.8 \pm 0.5^{\mathrm{b}}$ & $193.1 \pm 2.1^{c}$ \\
\hline
\end{tabular}

${ }^{11}$ Inhibitory effects are expressed as the mean $\pm \mathrm{SD}$ of triplicate experiments.

${ }^{2)}$ Different letters $(\mathrm{a}-\mathrm{f})$ within the same column indicate significant differences $(\mathrm{p}<0.05)$.

${ }^{3)}$ Acarbose was used as a positive control.

성을 확인되었으며, 총 페놀 함량이 상대적으로 많이 함유 되어 있는 $\mathrm{EtOAc}$ 분획물에서 $\mathrm{ABTS}^{+}$라디칼을 효과적으로 소거하는 물질의 존재가 시사 되었으며, 이 활성은 추출물 상태의 활성으로 향후 각종 칼럼크로마토그래피 및 기기분 석을 활용하여 EtOAc 분획물에 함유되어 있는 우수한 $\mathrm{ABTS}^{+}$라디칼 소거활성 물질의 동정이 필요하다고 사료된 다.

\section{$\mathrm{a}-\mathrm{Glucosidase}$ 저해 활성 측정}

울릉도 전 지역에 자생하는 섬바디의 $70 \% \mathrm{MeOH}$ 추출물 및 유기용매 분획물을 대상으로 항 당뇨 활성과 관련된 a-glucosidase 저해활성 평가를 수행한 결과(Table 3), 섬바 디 $70 \% \mathrm{MeOH}$ 추출물의 $\mathrm{IC}_{50}$ 값이 $>500 \mu \mathrm{g} / \mathrm{mL}$ 로 상대적으 로 낮은 저해 활성을 나타냈다. 라디칼 소거활성 평가에서 상대적으로 우수한 소거활성을 나타낸 $\mathrm{EtOAc}$ 분획물의 경우 $\mathrm{IC}_{50}$ 값이 $229.3 \pm 2.3 \mu \mathrm{g} / \mathrm{mL}$ 로 준수한 a-glucosidase 저 해활성을 나타냈다. 저 극성 용매인 $n$-hexane 분획물의 $\mathrm{IC}_{50}$ 값이 $55.5 \pm 0.4 \mu \mathrm{g} / \mathrm{mL}$ 로 가장 우수한 a-glucosidase 저해활성 을 나타냈으며, 양성대조군인 acarbose $\left(\mathrm{IC}_{50}=193.1 \pm 2.1 \mu\right.$ $\mathrm{g} / \mathrm{mL}$ )보다 3 배 이상 우수한 활성 보임을 확인하였다. 이전 연구결과 섬바디 $\mathrm{EtOH}$ 추출물의 $n$-hexane 분획물에서 polyacetylene류 화합물인 falcarindiol이 구조 동정 되었으 며(23), falcarindiol의 $\mathrm{IC}_{50}$ 값이 $67.7 \mu \mathrm{M}$ 로 매우 우수한 a -glucosidase 저해활성이 보고되었다(30). 본 연구 결과 역시 각종 유기용매 분획물 중에 $n$-hexane 분획물에서 상대적으 로 가장 우수한 a-glucosidase 저해활성이 확인 되었으며, 섬바디 $70 \% \mathrm{MeOH}$ 추출물의 $n$-hexane 분획물에도 활성을 나타내는 저극성 화합물들이 많이 함유되어 있을 것이라고 추정 된다. 향후 활성을 나타낸 $n$-hexane 분획물을 각종 칼럼크로마토그래피 및 기기 분석을 활용하여 활성물질의 동정이 필요하며, 세포 및 동물실험 등의 추가적인 효능 검증을 실시하여 우수한 a-glucosidase 저해제로서 가능성 을 검증할 필요가 있다고 생각된다.

\section{요 약}

울릉도에 자생하는 섬바디를 $70 \% \mathrm{MeOH}$ 로 침지 추출하 여 얻어진 추출물에 대해 각종 유기용매를 활용하여 순차 분획을 실시하였고, 얻어진 추출물 및 분획물을 대상으로 총 페놀 함량, $\mathrm{DPPH}, \mathrm{ABTS}^{+}$라디칼 소거활성 및 $\mathrm{a}$ -glucosidase 저해활성 평가를 수행하였다. DPPH 라디칼 소거활성 평가에서 페놀성 화합물이 가장 많이 함유되어 있는 $\mathrm{EtOAc}$ 분획물의 $\mathrm{IC}_{50}$ 값이 $127.3 \pm 2.1 \mu \mathrm{g} / \mathrm{mL}$ 을 나타냈 으며, $\mathrm{ABTS}^{+}$라디칼 소거활성 평가 역시 $\mathrm{EtOAc}$ 분획물의 $\mathrm{IC}_{50}$ 값이 $72.7 \pm 1.2 \mu \mathrm{g} / \mathrm{mL}$ 으로 가장 우수한 라디칼 소거활 성을 나타내었다. 항 당뇨활성과 관련된 a-glucosidase 저해 활성 평가에서는 $n$-hexane 분획물의 $\mathrm{IC}_{50}$ 값이 $55.5 \pm 0.4 \mu$ $\mathrm{g} / \mathrm{mL}$ 로 가장 우수한 저해활성을 나타내었으며, 이전 연구 결과와 비교해볼 때 $n$-hexane 분획물에 우수한 $a$ -glucosidase 저해활성을 나타내는 polyacetylene과 같은 저 해활성이 강한 화합물이 다량 함유되어 있을 것으로 추정한 다. 다양한 화합물이 함유된 상태의 추출물 시료를 단일물 질로 정제할 경우 더욱 우수한 활성의 화합물이 존재할 가능성을 확인하였으며, 향후 이들 추출물의 활성물질 동 정을 통한 활성 기작에 대한 연구가 필요하며, 본 연구결과 로 보다 우수한 라디칼 소거활성 및 a-glucosidase 저해활성 을 가지는 새로운 천연 기능성 소재 발굴을 위한 기초자료 로 활용 가능할 것으로 사료된다.

\section{References}

1. Fang YZ, Yang S, Wu G (2002) Free radicals, antioxidants, and nutrition. Nutrition, 18, 872-879

2. Halliwell B, Aruoma OI (1991) DNA damage by oxygen-derived species its mechanism and measurement in mammalian systems. FEBS Lett, 281, 9-19 
3. Klaunig JE, Kamendulis LM (2004) The role of oxidative stress in carcinogenesis. Annu Rev Pharmacol Toxicol, 44, 239-267

4. Huang D, Ou B, Prior RL (2005) The chemistry behind antioxidant capacity assays. J Agric Food Chem, 53, 1841-1856

5. Jennings BH, Akoh CC (2009) Effectiveness of natural versus synthetic antioxidants in a rice bran oil-based structured lipid. Food Chem, 114, 1456-1461

6. Farag RS, Badei AZMA, Hewedi FM, El Baroty GSA (1989). Antioxidant activity of some spice essential oils on linoleic acid oxidation in aqueous media. J Am Oil Chem Soc, 66, 792-799

7. Madsen HL, Bertelsen G (1995) Spices as antioxidants. Trends Food Sci Technol, 6, 271-277

8. Dapkevicius A, Venskutonis R, van Beek TA, Linssen JP (1998) Antioxidant activity of extracts obtained by different isolation procedures from some aromatic herbs grown in Lithuania. J Sci Food Agric, 77, 140-146

9. Yanishlieva NV, Marinova E, Pokorny J (2006) Natural antioxidants from herbs and spices. Eur J Lipid Sci Technol, 108, 776-793

10. Fava S (2008) Role of postprandial hyperglycemia in cardiovascular disease. Expert Rev Cardiovasc Ther, 6, 859-872

11. Israili $\mathrm{ZH}$ (2011) Advances in the treatment of type 2 diabetes mellitus. Am J Ther, 18, 117-152

12. Hsieh CT, Hsieh TJ, El-Shazly M, Chuang DW, Tsai YH, Yen CT, Wu SF, Wu YC, Chang FR (2012) Synthesis of chalcone derivatives as potential anti-diabetic agents. Bioorg Med Chem Lett, 22, 3912-3915

13. Duarte PM, Bezerra JP, Miranda TS, Feres M, Chambrone L, Shaddox LM (2014) Local levels of inflammatory mediators in uncontrolled type 2 diabetic subjects with chronic periodontitis. J Clin Periodontol, 41, 11-18

14. Asano N, Tomioka E, Kizu H, Matsui K (1994) Sugars with nitrogen in the ring isolated from the leaves of Morus bombycis. Carbohydr Res, 253, 235-245.

15. Mata R, Cristians S, Escandon-Rivera S, Juarez-Reyes K, Rivero-Cruz I (2013) Mexican antidiabetic herbs: valuable sources of inhibitors of a-glucosidases. J Nat Prod, 76, 468-483

16. Kim JH, Ryu YB, Kang NS, Lee BW, Heo JS, Jeong IY, Park KH (2006) Biol Pharm Bull, 29, 302-305

17. Omar R, Li L, Yuan T, Seeram NP (2012) a-Glucosidase inhibitory hydrolyzable tannins from Eugenia jambolana seeds. J Nat Prod, 75, 1505-1509

18. Choi J, Yoon KD, Kim J (2018) Chemical constituents from Taraxacum officinale and their a-glucosidase inhibitory activities. Bioorg Med Chem Lett, 28, 476-481

19. Ha MT, Seong SH, Nguyen TD, Cho WK, Ah KJ, Ma JY, Woo MH, Choi JS, Min BS (2018) Chalcone derivatives from the root bark of Morus alba L. act as inhibitors of PTP1B and a-glucosidase. Phytochemistry, $155,114-125$

20. Yin XF, Jeon YE, Chung HC, Choung SY, Shim JH, Kang IJ (2015) In vitro efficacy evaluation for prevention of diabetes and diabetic complications using Aster sphathulifolius. Food Sci Biotechnol, 24, 301-306

21. Pfosser M Jakubowsky G, Schlüter PM, Fer T, Kato H, Stuessy TF, Sun BY (2005) Evolution of Dystaenia takesimana (Apiaceae), endemic to Ullung Island, Korea. Pl Syst Evol, 256, 159-170

22. Kim JS, Kim JC, Shim SH, Lee EJ, Jin WY, Bae K, Son KH, Kim HP, Kang SS, Chang HW (2006) Chemical constituents of the root of Dystaenia takeshimana and their anti-inflammatory activity. Arch Pharm Res, 29, 617-623

23. Oh JA, Shin DH, Baek NI (1999) Isolation and identification of growth inhibition substance on $L$. monocytogenes from Dystaenia takesimana Kitagawa. Korean J Food Sci Technol, 31, 984-993

24. Tawaha K, Alali FQ, Gharaibeh M, Mohammad M, El-Elimat T (2007) Antioxidant activity and total phenolic content of selected Jordanian plant species. Food Chem, 104, 1372-1378

25. Blois MS (1958) Antioxidant determinations by the use of a stable free radical. Nature, 181, 1199-1200

26. Re R, Pellegrini N, Proteggente A, Pannala A, Yang M, Rice-Evans C (1999) Antioxidant activity applying an improved ABTS radical cation decolorization assay. Free Radical Bio Med, 26, 1231-1237

27. Kim TH (2016) A novel a-glucosidase inhibitory constituent from Uncaria gambir. J Nat Med, 70, 811-815

28. Sang S, Cheng X, Stark RE, Rosen RT, Yang CS, Ho CT (2002) Chemical studies on antioxidant mechanism of tea catechins: analysis of radical reaction products of catechin and epicatechin with 2, 2-diphenyl-1picrylhydrazyl. Bioorg Med Chem, 10, 2233-2237

29. Wang SY, Chang HN, Lin KT, Lo CP, Yang NS, Shyur LF (2003) Antioxidant properties and phytochemical characteristics of extracts from Lactuca indica. J Agric 
Food Chem, 51, 1506-1512

30. Thuong PT, Kang HJ, Na M, Jin W, Youn UJ, Seong YH, Song KS, Min BS, Bae K (2007) Anti-oxidant constituents from Sedum takesimense. Phytochemistry, $68,2432-2438$
31. Chan HH, Sun HD, Reddy MVB, Wu TS (2010) Potent a-glucosidase inhibitors from the roots of Panax japonicus CA Meyer var. major. Phytochemistry, 71, 1360-1364 